\title{
Anaerobaculum thermoterrenum gen. nov., sp. nov., a Novel, Thermophilic Bacterium Which Ferments Citrate
}

\author{
GAVIN N. REES, ${ }^{*}$ BHARAT K. C. PATEL, ${ }^{2}$ GINO S. GRASSIA, ${ }^{1}$ AND ALAN J. SHEEHY ${ }^{1}$ \\ Microbiology Research Unit, Faculty of Applied Science, University of Canberra, Belconnen, ACT 2616, ${ }^{1}$ \\ and School of Biomolecular and Biomedical Sciences, Faculty of Science and Technology, \\ Griffith University, Nathan, Queensland $4111,{ }^{2}$ Australia
}

\begin{abstract}
A thermophilic anaerobic bacterium designated strain RWcit2 $^{T}(T=$ type strain $)$ was isolated from the production water of a petroleum reservoir. The cells of this organism are straight to slightly curved rods that are gram negative and nonmotile. Spore formation has not been demonstrated. Growth occurs at temperatures ranging from 28 to $60^{\circ} \mathrm{C}$, with optimum growth occurring at $55^{\circ} \mathrm{C}$, and at pH values ranging from 5.5 to 8.6 , with optimum growth occurring between $\mathrm{pH} 7$ and 7.6. Growth occurs in media containing 0 to $20 \mathrm{~g}$ of $\mathrm{NaCl}$ per liter, and optimum growth occurs in the presence of $10 \mathrm{~g}$ of $\mathrm{NaCl}$ per liter. Strain $\mathrm{RWcit} 2^{\mathrm{T}}$ grows on a range of organic acids, including citrate, pyruvate, malate, fumarate, and tartrate; on protein extracts; and on a limited number of carbohydrates. Sulfur, thiosulfate, and cystine are reduced to hydrogen sulfide. Sulfate, sulfite, and nitrate are not reduced. The DNA base composition is $44 \mathrm{~mol} \% \mathrm{G}+\mathrm{C}$. The $16 \mathrm{~S}$ ribosomal DNA sequence revealed that strain $\mathrm{RWcit}^{\mathrm{T}}$ is a member of the domain Bacteria and forms a branch that is approximately equidistant from Dictyoglomus thermophilum and Thermoanaerobacter spp. (level of similarity, $82 \%$ ). Strain RWcit ${ }^{\mathrm{T}}$ cannot be placed in any previously described taxon based on its phylogenetic and physiological traits and is named Anaerobaculum thermoterrenum gen. nov., sp. nov.
\end{abstract}

It is now recognized that a range of thermophilic and hyperthermophilic microorganisms can be isolated from petroleum reservoir fluids. Complex media containing biological peptones, yeast extract, and carbohydrates have been used successfully for the isolation of these microorganisms $(14,19$, 27). Investigations into anaerobic organic acid degradation by petroleum reservoir microorganisms have been confined to oxidation by sulfate-reducing bacteria $(3,16,20,28)$ and aceticlastic methanogens (4). In contrast, organic acids, which are known to occur in petroleum reservoirs and are potential substrates, have not been widely reported as compounds that support the growth of thermophilic fermentative bacteria. The reports which have occurred have involved organic acid fermentation by thermophilic microorganisms subsequent to their isolation on other substrates (10).

In this paper we described the isolation and characterization of a thermophilic fermentative microorganism, designated strain $R W c i t 2^{T}$ ( $T=$ type strain), which is able to degrade organic acids.

\section{MATERIALS AND METHODS}

Source of organism. Strain RWcit $2^{\mathrm{T}}$ was isolated from production fluid from the Redwash oil field in Utah. The Redwash oil field has a depth of $1,524 \mathrm{~m}$, a temperature of approximately $52^{\circ} \mathrm{C}$, and a salinity of $25 \mathrm{~g}$ per liter. River water is injected into the field as part of the secondary oil recovery processes.

Media and culture conditions. Anaerobic procedures used in the preparation of media and cultivation of anaerobic microorganisms have been described previously $(25,28)$. For enrichment and purification of strain $\mathrm{RWcit} 2^{\mathrm{T}}$, brackish bicarbonate-buffered, sulfide-reduced medium (34) was prepared without sodium sulfate to eliminate possible growth of sulfate-reducing bacteria. The additions to the medium were $0.1 \mathrm{~g}$ of yeast extract per liter, trace element solution SL-10 (17), and the vitamin solution of Wolin et al. (37). Following purification of strain RWcit $2^{\mathrm{T}}, 0.1 \mathrm{~g}$ of $\mathrm{Na}_{2} \mathrm{SO}_{4}$ per liter was included in the culture medium as an inorganic sulfur source. Complex medium MMB was modified from MB medium (27) and contained (per liter) $0.5 \mathrm{~g}$ of $\mathrm{NH}_{4} \mathrm{Cl}, 0.3 \mathrm{~g}$ of $\mathrm{K}_{2} \mathrm{HPO}_{4}, 0.3 \mathrm{~g}$ of $\mathrm{KH}_{2} \mathrm{PO}_{4}, 0.2 \mathrm{~g}$ of $\mathrm{MgCl}_{2} \cdot 6 \mathrm{H}_{2} \mathrm{O}, 0.1 \mathrm{~g}$ of $\mathrm{CaCl}_{2} \cdot 2 \mathrm{H}_{2} \mathrm{O}, 5.0 \mathrm{~g}$ of $\mathrm{NaCl}, 0.1 \mathrm{~g}$ of $\mathrm{KCl}, 0.8 \mathrm{~g}$ of sodium acetate $\cdot 3 \mathrm{H}_{2} \mathrm{O}, 0.5 \mathrm{~g}$ of cysteine- $\mathrm{HCl}, 5.0 \mathrm{~g}$ of yeast extract (Oxoid), $5.0 \mathrm{~g}$ of tryptone (Oxoid), $0.001 \mathrm{~g}$ of resazurin, and $1 \mathrm{ml}$ of solution

* Corresponding author. Phone: 616201 2381. Fax: 6162516361. E-mail: rees@science.canberra.edu.au.
SL-10. The $\mathrm{pH}$ of the medium was adjusted to 7 , and the medium was dispensed anaerobically under oxygen-free nitrogen. Anaerobic agar plates were prepared by including $2.0 \mathrm{~g}$ of agar per liter in MMB medium. Autoclaved agar was cooled and plates were poured in an anaerobic chamber. Inoculated plates were incubated in anaerobic sealed jars at $50^{\circ} \mathrm{C}$. Substrate tests were carried out by using the brackish bicarbonate-buffered medium supplemented with $0.1 \mathrm{~g}$ of yeast extract per liter in the presence and absence of elemental sulfur $(2 \%, \mathrm{wt} / \mathrm{vol})$ Media containing sulfur were autoclaved at $110^{\circ} \mathrm{C}$ for $30 \mathrm{~min}$. Cellulose powder, carboxymethyl cellulose, pectin, and soluble starch were each added at a concentration of $2.0 \mathrm{~g}$ per liter directly to culture vessels before media were dispensed.

Enrichment, isolation, and purification. Strain RWcit $2^{\mathrm{T}}$ was enriched from Redwash field production water in brackish bicarbonate-buffered medium containing $10 \mathrm{mM}$ citrate and incubated at $50^{\circ} \mathrm{C}$. Enrichment cultures were maintained for at least five subcultures in bicarbonate-buffered medium containing citrate. Culture purification was achieved by the agar shake-dilution tube process (34). Purity was confirmed by microscopically examining cultures inoculated into medium containing citrate, pyruvate, and peptone; cooked meat medium (Difco); and thioglycolate broth (Difco).

Cellular characterization. The Gram type was determined by staining (11) and by the KOH lysis method (5). The ability of strain RWcit $2^{\mathrm{T}}$ to produce spores was examined in cooked meat medium (Difco) supplemented with $5.0 \mathrm{~g}$ of $\mathrm{NaCl}$ per liter, AE sporulation medium (2), xylose medium (7), and mineral media containing $10 \mathrm{mM}$ citrate supplemented with either $2 \%$ (vol/vol) soil extract, $0.05 \mathrm{~g}$ of $\mathrm{MnSO}_{4}$ per liter, or $300 \mathrm{mg}$ of thiamine- $\mathrm{HCl}$ per liter. All cultures were examined microscopically for spores and then heated at $90^{\circ} \mathrm{C}$ for $5 \mathrm{~min}$ and inoculated into fresh medium. Phase-contrast micrographs were taken by using agar-coated slides (26) and a Leica diaplan microscope. Negative staining and preparation of thin sections for electron microscopy were performed as described previously (24). DNA base composition was determined by the thermal denaturation method (22), using DNA purification procedures described by Owen and Lapage (23). Cytochromes were characterized as described by Janssen and Harfoot (18).

Temperature, salinity, and $\mathrm{pH}$ experiments were carried out in 20-ml tubes (Bellco) containing $10 \mathrm{ml}$ of MMB medium supplemented with $10 \mathrm{mM}$ thiosulfate. The optical density was determined between day 4 and day 5 of incubation, which corresponded to mid-growth in optimally growing cells.

For $\mathrm{H}_{2}$ inhibition experiments, 120 -ml serum bottles containing $20 \mathrm{ml}$ of MMB medium and $\mathrm{N}_{2}$ as the headspace gas were prepared, inoculated, and subjected to $1 \mathrm{~atm}$ of overpressure of $\mathrm{H}_{2}-\mathrm{CO}_{2}(80: 20)$ or $\mathrm{N}_{2}-\mathrm{CO}_{2}(80: 20)$. Optical density at $580 \mathrm{~nm}$ was determined after 1 week of incubation. All growth experiments were begun with a $1 \%(\mathrm{vol} / \mathrm{vol})$ inoculum.

Molecular characterization. The PCR product of the 16S rRNA gene was sequenced directly with an $\mathrm{ABI}$ automated sequencer by using a prism dideoxy terminator cycle sequencing kit according to the recommendations of the manufacturer (Applied Biosystems, Foster City, Calif.). All of the procedures used for phylogenetic analysis have been described previously (28). A nearly complete sequence consisting of 1,526 bases was obtained, but only 1,189 unambiguous 


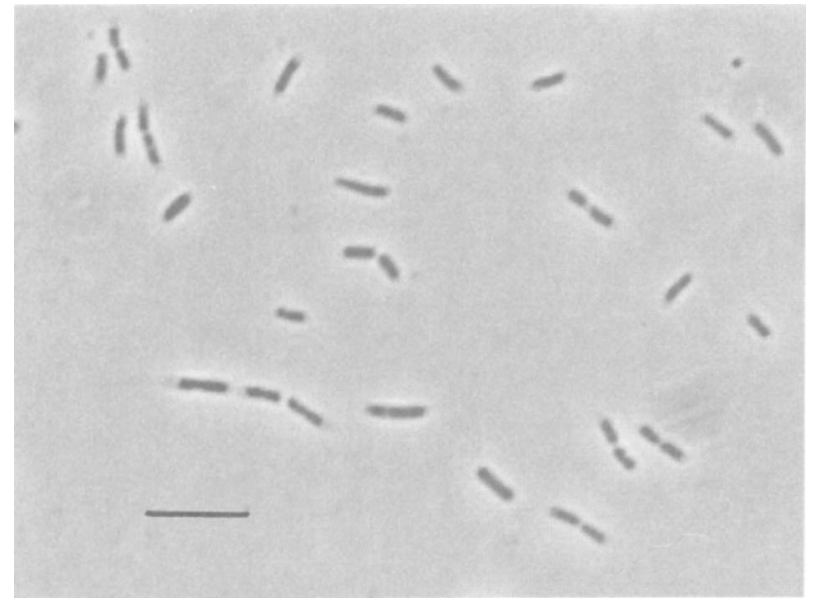

FIG. 1. Phase-contrast micrograph of strain $\mathrm{RWcit}^{\mathrm{T}}$. Bar $=5 \mu \mathrm{m}$. Cells were grown in MMB medium.

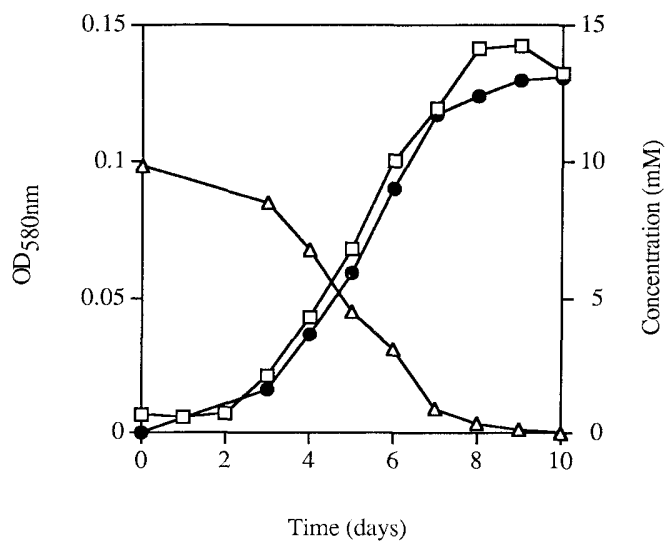

FIG. 2. Growth of strain RWcit $2^{\mathrm{T}}$ on citrate. The bicarbonate-buffered medium contained mineral salts, $10 \mathrm{mM}$ citrate, and vitamins (see Materials and Methods). Symbols: $\square$, optical density at $580 \mathrm{~nm}\left(\mathrm{OD}_{580 \mathrm{~nm}}\right) ; \triangle$, citrate concentration; - acetate concentration. positions were used in pairwise evolutionary distance calculations with the algorithm of Jukes and Cantor. A phylogenetic tree was drawn by using the neighborjoining method. A bootstrap analysis was performed by using DBOOT and CONSENSE. All computer programs used for the taxonomic analyses are part of the PHYLIP package (13). The sequence was also analyzed by using SUGGEST TREE, which forms part of the Ribosomal Database Project; SUGGEST TREE implements the program fastDNAml (21).

Analytical techniques. Growth was determined by removing samples from culture vessels and determining the optical density at $580 \mathrm{~nm}(1-\mathrm{cm}$ light path) with a Cary 3 spectrophotometer (Varian, Melbourne, Australia). Resazurin was omitted from media on which optical density measurements were made. A Shimadzu gas chromatograph fitted with a type BP21 column $(12 \mathrm{~m}$ by $0.32 \mathrm{~mm}$; SGE, Melbourne, Australia) and a flame ionization detector was used to quantify short-chain monocarboxylic acids. Samples used for gas chromatographic analysis were acidified in $0.03 \mathrm{M}$ oxalic acid prior to injection. A Waters highpressure liquid chromatography (HPLC) system fitted with a Bio-Rad type HPX$87 \mathrm{H}$ column and UV and refractive index detectors also was used to detect and quantify organic compounds. The column was maintained at $50^{\circ} \mathrm{C}$, and a mobile phase $\left(0.005 \mathrm{M} \mathrm{H}_{2} \mathrm{SO}_{4}\right)$ at a flow rate of $0.5 \mathrm{ml}$ per min was used. Sulfide was measured as described by Trüper and Schlegel (33). Nitrate reduction was monitored as described by Smibert and Krieg (31).

Nucleotide sequence accession number. The $16 \mathrm{~S}$ ribosomal DNA sequence of strain RWcit $2^{\mathrm{T}}$ has been deposited in the GenBank database under accession number U50711.

\section{RESULTS}

Enrichment and isolation of strain RWcit2 ${ }^{\mathrm{T}}$. Enrichment cultures containing citrate grew within 3 to 5 days of inoculation. The primary enrichment culture contained microorganisms with diverse morphologies, but subsequent subcultures were dominated by small rod-shaped cells. A pure culture of these cells was designated RWcit ${ }^{\mathrm{T}}$. Colonies in agar shake dilution tubes were white and lens shaped. Colonies grown on agar plates for 3 weeks were 1 to $2 \mathrm{~mm}$ in diameter. circular with entire margins, smooth with shiny surfaces, and white with opaque sectors.

Cellular characteristics. Strain RWcit $2^{\Gamma}$ cells grown on citrate were generally 0.75 by $2 \mu \mathrm{m}$ (Fig. 1). Sheath-like material extending past the cell poles was evident in cells grown on complex MMB medium. No such material was evident in cells grown on citrate. The cells stained gram negative, but their reaction in the $\mathrm{KOH}$ lysis test was intermediate between the reactions of Escherichia coli and Staphylococcus aureus. Spores were never observed in any of the sporulation test media, and the cultures did not survive heat treatment. The cells were nonmotile, and flagella were not observed in negatively stained electron microscope preparations (data not shown).
Physiological characteristics. Strain RWcit ${ }^{\mathrm{T}}$ grew in defined medium supplemented with vitamins and with citrate as the sole carbon and energy source (Fig. 2). When strain RWcit $2^{\mathrm{T}}$ grew on citrate, acetate was produced, and the molar ratio of amount of acetate produced to amount of citrate degraded was approximately 1:1. HPLC elution traces of culture supernatant also revealed that another metabolite was produced during growth on citrate, but the retention time of this metabolite did not correspond to the retention times of known end products of citrate fermentation. Further analysis demonstrated that succinate, isocitrate, trans-aconitate, tricarballylic acid, glyoxylate, and oxalate were not present. The identity of the other metabolite remains unknown and is being investigated.

The compounds that strain RWcit ${ }^{\mathrm{T}}$ was able to use for growth were citrate $(10 \mathrm{mM})$, fumarate $(10 \mathrm{mM})$, malate $(10$ $\mathrm{mM})$, pyruvate $(10 \mathrm{mM})$, glutamate $(10 \mathrm{mM}), \alpha$-ketoglutarate $(10 \mathrm{mM})$, tartrate $(10 \mathrm{mM})$, tryptone $(2 \mathrm{~g} /$ liter $)$, Biological peptone (Oxoid catalog no. L-37) ( $2 \mathrm{~g} / \mathrm{liter}$ ), starch ( $2 \mathrm{~g} / \mathrm{liter}$ ), pectin $(1 \mathrm{~g} /$ liter $)$, glucose $(5 \mathrm{mM})$, fructose $(5 \mathrm{mM})$, mannose $(5 \mathrm{mM})$, inositol (1 g/liter), and glycerol (1 g/liter). No growth occurred on xylose $(5 \mathrm{mM})$, galactose $(5 \mathrm{mM})$, lactose $(2 \mathrm{mM})$, sucrose $(2 \mathrm{mM})$, maltose $(2 \mathrm{mM})$, rhamnose $(2 \mathrm{mM})$, raffinose $(1 \mathrm{mM})$, cellulose $(2 \mathrm{~g} / \mathrm{liter})$, carboxymethyl cellulose $(2 \mathrm{~g} / \mathrm{li}$ ter), gum arabic $(2 \mathrm{~g} /$ liter $)$, malonate $(10 \mathrm{mM})$, succinate $(10$ $\mathrm{mM})$, glutarate $(10 \mathrm{mM})$, and lactate $(10 \mathrm{mM})$.

Strain RWcit ${ }^{\mathrm{T}}$ grew in complex medium MMB (Fig. 3). When elemental sulfur was included in the medium, the growth of strain RWcit $2^{\mathrm{T}}$ was biphasic. Initially, growth was slightly faster in the presence of sulfur compared to controls without sulfur. After approximately $70 \mathrm{~h}$ of incubation, the cells in the medium without sulfur were in a death phase, whereas the cells in the medium containing sulfur showed an increase in growth. A marked increase in sulfide production occurred concomitant with this increased growth. Cystine and thiosulfate also could be reduced to hydrogen sulfide by strain $\mathrm{RWcit} 2^{\mathrm{T}}$. Thiosulfate reduction proceeded directly to sulfide, without formation of elemental sulfur. Sulfate and nitrate (both at a concentration of $10 \mathrm{mM}$ ) were not used as electron acceptors and did not affect the growth of strain RWcit $2^{\mathrm{T}}$. Sulfite was not reduced, and concentrations greater than $1 \mathrm{mM}$ inhibited growth.

Strain RWcit $2^{\mathrm{T}}$ produced a range of carboxylic acids when it was grown on MMB medium and glucose (Table 1), and sig- 


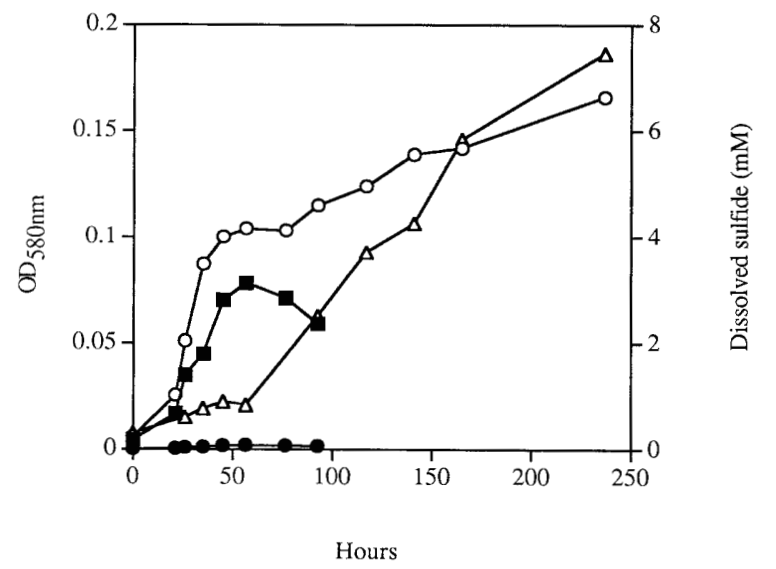

FIG. 3. Growth of strain RWcit $2^{\mathbf{T}}$ on $\mathrm{MMB}$ medium in the presence and absence of $10 \mathrm{mM}$ sulfur. Symbols: $O$, optical density at $580 \mathrm{~nm}\left(\mathrm{OD}_{580 \mathrm{~nm}}\right)$ in the presence of sulfur; $\square$, optical density in the absence of sulfur; $\Delta$, sulfide production in the presence of sulfur; 9 , sulfide production in the absence of sulfur.

nificantly higher end product concentrations occurred in the presence of elemental sulfur. Butyrate, lactate, and ethanol were not produced when strain RWcit $2^{\mathrm{T}}$ grew on glucose. A 1-atm overpressure of $\mathrm{H}_{2}-\mathrm{CO}_{2}$ applied to cultures caused almost complete inhibition of growth compared to controls pressurized with $\mathrm{N}_{2}-\mathrm{CO}_{2}$. An overpressure of $\mathrm{N}_{2}-\mathrm{CO}_{2}$ had no effect on the growth of strain RWcit $2^{\mathrm{T}}$.

The optimum temperature for growth was $55^{\circ} \mathrm{C}$, and the maximum temperature for growth was $60^{\circ} \mathrm{C}$. Cultures incubated at $28^{\circ} \mathrm{C}$ grew very slowly and after 2 weeks had an optical density of 0.07 . Growth occurred in media containing 0 to $20 \mathrm{~g}$ of $\mathrm{NaCl}$ per liter, and optimum growth occurred in medium containing $10 \mathrm{~g}$ of $\mathrm{NaCl}$ per liter. Growth occuried at $\mathrm{pHs}$ ranging from 5.5 to 8.6 , and the optimum $\mathrm{pH}$ was between 7 and 7.6 .

Strain RWcit $2^{\mathrm{T}}$ was able to grow in anoxic MMB medium without a reducing agent. No growth occurred in medium that remained aerobic throughout the incubation period.

Biochemical characteristics. Strain RWcit $2^{\mathrm{T}}$ was catalase negative. Cells did not hydrolyze gelatin or produce indole from tryptophan. The base composition of DNA isolated from strain RWcit $2^{\mathrm{T}}$ was $44 \mathrm{~mol} \% \mathrm{G}+\mathrm{C}$. Cytochromes were not detected in dithionite-reduced-minus-air-oxidized difference spectra.

Phylogeny. The dendrogram in Fig. 4 shows the phylogenetic position of strain RWcit $2^{\mathrm{T}}$ among related bacteria. An analysis of its $16 \mathrm{~S}$ rRNA gene sequence showed that strain RWcit ${ }^{\mathrm{T}}$ formed a branch that was approximately equidistant from Dictyoglomus thermophilum (level of similarity, $81.7 \%$ ) and Thermoanaerobacter brockii (level of similarity, $82.3 \%$ ). The boot-

TABLE 1. End products formed by RWcit $2^{\mathrm{T}}$ growing on complex medium containing tryptone and yeast extract

\begin{tabular}{lccccc}
\hline \multirow{2}{*}{ Medium } & \multicolumn{5}{c}{ End product concn $(\mathrm{mM})$} \\
\cline { 2 - 6 } & Acetate & Propionate & Isobutyrate & Isovalerate & Sulfide \\
\hline $\mathrm{MMB}$ & 4.7 & 1.1 & $\mathrm{ND}^{a}$ & 1.4 & $\mathrm{ND}$ \\
$\mathrm{MMB}+$ glucose & 11.0 & 0.9 & $\mathrm{ND}$ & 0.8 & $\mathrm{ND}$ \\
$\mathrm{MMB}+$ sulfur & 15.3 & 4.4 & 2.1 & 4.9 & 25.9 \\
MMB + glucose & 14.0 & 2.0 & 1.0 & 3.1 & 18.7 \\
$\quad$ & & & & & \\
\hline
\end{tabular}

a ND, not detected (detection limit, $0.1 \mathrm{mM}$ ).

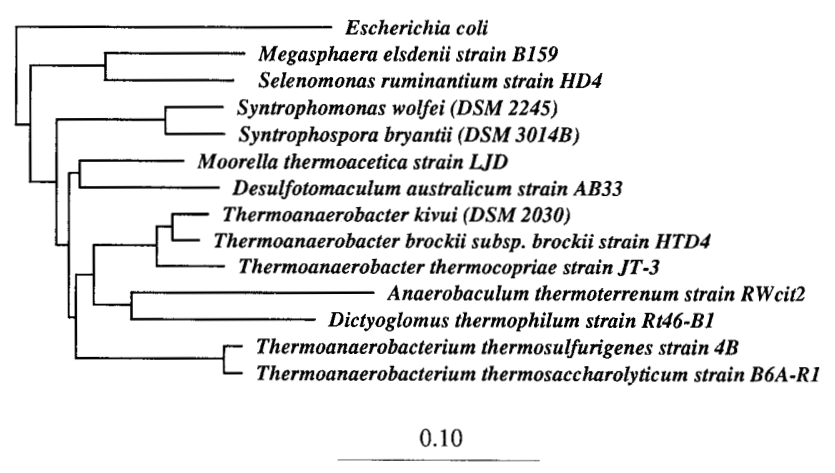

FIG. 4. Phylogenetic position of strain RWcit $2^{\mathrm{T}}$ within the radiation of $D$. thermophilum, Thermoanaerobacter spp., and reference organisms. Bar = evolutionary distance of 0.1 .

strap analysis results obtained with Thermoanaerobacter brockii were robust (level of relatedness, $100 \%$ ), whereas the level of relatedness with $D$. thermophilum was $72 \%$. The levels of relatedness may increase as additional sequence data are obtained from new strains.

\section{DISCUSSION}

Strain RWcit $2^{\mathrm{T}}$ is an anaerobic, thermophilic bacterium with an optimum growth temperature of $55^{\circ} \mathrm{C}$. This strain is able to ferment several organic acids, as well as protein extracts and a limited number of carbohydrates. Extensive organic acid degradation by thermophilic fermentative bacteria has not been reported previously.

A phylogenetic analysis based on $16 \mathrm{~S}$ ribosomal DNA comparisons demonstrated that strain $\mathrm{RWcit} 2^{\mathrm{T}}$ is almost equidistant from Thermoanaerobacter spp. and $D$. thermophilum and forms a distinct line of descent. The current lack of sequence data for this region of the phylogenetic tree means that the exact position of the branch cannot be determined precisely. The exact position will become clearer as new sequence data become available.

Strain RWcit $2^{\mathrm{T}}$ shares some characteristics with its phylogenetic relatives, but there are also significant differences. The end products formed from peptone degradation by strain $\mathrm{RW}$ cit $2^{\mathrm{T}}$ are similar to the end products formed by several thermophilic fermentative bacteria, including Thermoanaerobacter spp., as these organisms produce acetate, isovalerate, and isobutyrate as major products and propionate as a minor product during peptide fermentation $(12,35)$. The end products produced by Thermoanaerobacter spp. from glucose fermentation are acetate, ethanol, and lactate, and the actual products and product ratios are species dependent (6). Strain RWcit $2^{\mathrm{T}}$ differed from Thermoanaerobacter species in that it did not produce lactate or ethanol. In general, carbohydrate degradation by strain RWcit $2^{\mathrm{T}}$ is significantly more restricted than carbohydrate degradation by Thermoanaerobacter species. Thiosulfate reduction as a means of eliminating inhibition by hydrogen has been described in Thermoanaerobacter spp. (12) and members of the Thermotogales (19); however, some Thermotoga spp. are inhibited by elemental sulfur (19, 27, 36). Strain RWcit $2^{\mathrm{T}}$ could reduce sulfur, thiosulfate, and cystine. Cystine reduction has been described in Thermotoga subterranea (19).

Strain RWcit $2^{\mathrm{T}}$ has a significantly higher $\mathrm{G}+\mathrm{C}$ content than $D$. thermophilum (44 and $29 \mathrm{~mol} \%$, respectively). Strain RWcit $2^{\mathrm{T}}$ can degrade starch but in general differs from $D$. 
thermophilum in its substrate utilization patterns and the end products formed from glucose fermentation (29). Dictyoglomus spp. cells form large bundles, termed rotund bodies, in the late log phase, whereas members of the Thermotogales, Geotoga spp., and Petrotoga spp. always produce a "sheath" (9). Sheathlike material was observed in strain $\mathrm{RWcit} 2^{\mathrm{T}}$, but this was an intermittent phenomenon. Rotund bodies have never been observed in strain RWcit2 ${ }^{\mathrm{T}}$.

Several pathways for citrate degradation have been found in mesophilic bacteria. Ruminococcus pasteurii and Formivibrio citricus produce acetate plus formate $(30,32)$; Acidaminococcus fermentans produces acetate, butyrate, and $\mathrm{H}_{2}$ (8); Clostridium sphenoides produces acetate plus ethanol (1); and Streptococcus diacetylactis produces a mixture of acetate, diacetyl, acetoin, 2,3-butandiol, and $\alpha$-acetoacetate (15). At present, the metabolites formed during citrate degradation by strain RWcit $2^{\mathrm{T}}$ have not been fully elucidated, but they clearly differ from the metabolites described previously for certain mesophilic microorganisms. This suggests that citrate metabolism by strain RWcit ${ }^{\mathrm{T}}$ may occur via a different pathway than the pathways described previously. Citrate degradation is the key physiological difference between strain $\mathrm{RWcit} 2^{\mathrm{T}}$ and all other thermophilic microorganisms that have been described. The characteristics of strain RWcit $2^{\mathrm{T}}$ are not consistent with the physiology or phylogeny of any previously described taxon. We propose the name Anaerobaculum thermoterrenum gen. nov., sp. nov. for this organism.

Description of Anaerobaculum gen. nov. Anaerobaculum (An.ae.ro.ba'cu.lum. Gr. pref. an, not; Gr. n. aer, air; L. neut. n. baculum, small stick; M. L. n. Anaerobaculum, rod growing in the absence of air). Chemoorganotrophic anaerobe. Nonmotile, straight to slightly curved rods. In complex media, cells grow with sheath-like material extending past the cell poles. Endospores are not produced. Cells stain gram negative. Ferments a range of organic acids, protein extracts, and a limited number of carbohydrates. Belongs to the domain Bacteria and forms a branch approximately equidistant from $D$. thermophilum and Thermoanaerobacter spp. (level of similarity, approximately $82 \%$ ).

Description of Anaerobaculum thermoterrenum sp. nov. Anaerobaculum thermoterrenum (ther.mo.ter.re'num. Gr. adj. thermus, warm, hot; L. adj. terrenum, earthen, belonging to the earth; M. L. adj. thermoterrenum, from hot earth, describing the site of isolation).

Cells are 0.75 by $2 \mu \mathrm{m}$ and occur singly or in pairs. Obligately anaerobic. Grows very slowly at $28^{\circ} \mathrm{C}$, and the maximum temperature for growth is $60^{\circ} \mathrm{C}$; the optimum temperature is $55^{\circ} \mathrm{C}$. Growth occurs in medium containing 0 to $20 \mathrm{~g}$ of $\mathrm{NaCl}$ per liter; the optimum salinity is about $10 \mathrm{~g} /$ liter. Growth occurs at pHs ranging from 5.5 to 8.6 , and the optimum $\mathrm{pH}$ is between 7 and 7.6. Ferments citrate, fumarate, malate, pyruvate, glutamate, $\alpha$-ketoglutarate, tartrate, starch, pectin, glucose, fructose, mannose, inositol, glycerol, protein extracts, and Casamino Acids. Compounds that are not used are xylose, galactose, lactose, sucrose, maltose, rhamnose, raffinose, cellulose, carboxymethyl cellulose, gum arabic, malonate, succinate, glutarate, and lactate. Sulfide is produced when the organism is grown in the presence of elemental sulfur, thiosulfate, and cystine. Sulfate, sulfite, and nitrate are not reduced. Growth is inhibited by $\mathrm{H}_{2}$. The DNA base composition is $44 \mathrm{~mol} \% \mathrm{G}+\mathrm{C}$ (as determined by the thermal denaturation method). Cytochromes are not present.

Isolated from production fluid of a petroleum reservoir.

The type strain is RWcit2, which has been deposited in the Australian Collection of Microorganisms (University of Queensland, Brisbane, Australia) as strain ACM 5076.

\section{ACKNOWLEDGMENTS}

We thank C. Batum for skilled technical assistance and Live Oil Services and Chevron Inc. USA for providing production water samples. We thank G. Cook and P. Janssen for helpful discussions.

This work was supported by Land and General Berhad, Malaysia.

\section{REFERENCES}

1. Antranikian, G., C. Friese, A. Quentmeier, H. Hippe, and G. Gottschalk. 1984. Distribution of the ability for citrate utilization amongst clostridia. Arch. Microbiol. 138:179-182.

2. Atlas, R. 1993. Handbook of microbiological media. CRC Press, Boca Raton, Fla.

3. Beeder, J., T. Torsvik, and T. Lien. 1995. Thermodesulforhabdus norvegicus gen. nov., sp. nov., a novel thermophilic sulfate-reducing bacterium from oil field water. Arch. Microbiol. 164:331-336.

4. Belyaev, S. S., E. P. Rozanova, I. A. Borzenkov, I. A. Charakhch'yan, Y. M. Miller, M. Y. Sokolov, and M. V. Ivanov. 1990. Characteristics of microbiological processes in a water-flooded oilfield in the middle $\mathrm{Ob}^{\prime}$ region. $\mathrm{Mi}$ crobiology (Engl. Transl. Mikrobiologiya) 59:754-759.

5. Buck, J. D. 1982. Nonstaining (KOH) method for determination of Gram reactions of marine bacteria. Appl. Environ. Microbiol. 44:992-993.

6. Cayol, J. L., B. Ollivier, B. K. C. Patel, G. Ravot, M. Magot, E. Ageron, P. A. D. Grimont, and J. L. Garcia. 1995. Description of Thermoanaerobacter brockii subsp. lactiethylicus subsp. nov., isolated from a deep subsurface French oil well, a proposal to reclassify Thermoanaerobacter finnii as Thermoanaerobacter brockii subsp. finnii comb. nov., and an emended description of Thermoanaerobacter brockii. Int. J. Syst. Bacteriol. 45:783-789.

7. Cook, G. M., P. H. Janssen, and H. W. Morgan. 1991. Endospore formation by Thermoanaerobium brockii HTD4. Syst. Appl. Microbiol. 14:240-244.

8. Cook, G. M., F. A. Rainey, G. Chen, E. Stakebrandt, and J. B. Russell. 1994. Emendation of the description of Acidaminococcus fermentens, a trans-aconitate- and citrate-oxidizing bacterium. Int. J. Syst. Bacteriol. 44:576-578.

9. Davey, M. E., W. A. Wood, R. K. Key, K. Nakamura, and D. A. Stahl. 1993. Isolation of three species of Geotoga and Petrotoga: two new genera, representing a new lineage in the bacterial line of descent distantly related to the "Thermotogales." Syst. Appl. Microbiol. 16:191-200.

10. Davydova-Charakhch'yan, I. A., A. N. Mileeva, L. L. Mityushina, and S. S. Belyaev. 1992. Acetogenic bacteria from oil fields of Tataria and western Siberia. Microbiology (Engl. Transl. Mikrobiologiya) 61:208-216.

11. Doetsch, R. N. 1981. Determinative methods of light microscopy, p. 21-33. In P. Gerhardt, R. G. E. Murray, R. N. Costilow, E. W. Nester, W. A. Wood, N. R. Krieg, and G. B. Phillips (ed.), Manual of methods for general bacteriology. American Society for Microbiology, Washington, D.C.

12. Faudon, C., M. L. Fardeau, J. Heim, M. Magot, and B. Ollivier. 1995. Peptide and amino acid oxidation in the presence of thiosulfate by members of the genus Thermoanaerobacter. Curr. Microbiol. 31:152-157.

13. Felsenstein, J. 1993. PHYLIP (phylogenetic inference package), version 3.5.1c. Department of Genetics, University of Washington, Seattle.

14. Grassia, G. S. 1995. Ph.D. thesis. University of Canberra, Canberra, Australia.

15. Harvey, R. J., and E. B. Collins. 1961. Role of citritase in acetoin formation by Streptococcus diacetilactis and Leuconostoc citrovonum. J. Bacteriol. 82: 954-959.

16. Herbert, B. N., P. D. Gilbert, H. Stockdale, and R. J. Watkinson. 1985. Factors controlling the activity of sulphate-reducing bacteria in reservoirs during water injection. Proceedings of the Conference on Offshore Europe '85. Society of Petroleum Engineers publication 13978/10:1-10.

17. Imhoff-Stuckle, D., and N. Pfennig. 1983. Isolation and characterization of a nicotinic acid-degrading sulfate-reducing bacterium, Desulfococcus niacini sp. nov. Arch. Microbiol. 136:194-198.

18. Janssen, P. H., and C. G. Harfoot. 1990. Isolation of a Citrobacter species able to grow on malonate under strictly anaerobic conditions. J. Gen. Microbiol. 136:1037-1042.

19. Jeanthon, C., A. L. Reysenbach, S. L'Haridon, A. Gambacorta, N. R. Pace, P. Glénat, and D. Prieur. 1995. Thermotoga subterranea sp. nov., a new thermophilic bacterium isolated from a continental oil reservoir. Arch. Microbiol. 164:91-97.

20. Magot, M., P. Caumette, J. M. Desperrier, R. Matheron, C. Dauga, F. Grimont, and L. Carreau. 1992. Desulfovibrio longus sp. nov., a sulfatereducing bacterium isolated from an oil-producing well. Int. J. Syst. Bacteriol. 42:398-403.

21. Maidak, B. L., G. J. Olsen, N. Larsen, R. Overbeek, M. J. McCaughey, and C. R. Woese. 1996. The Ribosomal Database Project (RDP). Nucleic Acids Res. 24:82-85.

22. Mandel, M., and J. Marmur. 1968. Use of ultraviolet absorbance-temperature profile for determining the guanine plus cytosine content of DNA. Methods Enzymol. 3:195-206.

23. Owen, R. J., and S. P. Lapage. 1976. The thermal denaturation of partly purified bacterial deoxyribonucleic acid and its taxonomic applications. J. Appl. Bacteriol. 41:335-340.

24. Patel, B. K. C., H. W. Morgan, and R. M. Daniel. 1985. Fervidobacterium 
nodosum gen. nov. and spec. nov., a new chemoorganotrophic, caldoactive, anaerobic bacterium. Arch. Microbiol, 141:63-69.

25. Patel, B. K. C., H. W. Morgan, and R. M. Daniel. 1985. A simple and efficient method for preparing and dispensing anaerobic media. Biotechnol. Lett. 7:277-278.

26. Pfennig, N., and S. Wagener. 1986. An improved method of preparing wet mounts for photomicrographs of microorganisms. J. Microbiol. Methods 4:303-306

27. Ravot, G., M. Magot, M. L. Fardeau, B. K. C. Patel, G. Prensier, A. Egan, J. L. Garcia, and B. Ollivier. 1995. Thermotoga elfii sp. nov., a novel thermophilic bacterium from an African oil-producing well. Int. J. Syst. Bacteriol. 45:308-314.

28. Rees, G. N., G. S. Grassia, A. J. Sheehy, P. P. Dwivedi, and B. K. C. Patel. 1995. Desulfacinum infernum gen. nov., sp. nov., a thermophilic sulfatereducing bacterium from a petroleum reservoir. Int. J. Syst. Bacteriol. 45: $85-89$.

29. Saiki, T., Y. Kobayashi, K. Kawagoe, and T. Beppu. 1985. Dictyoglomus thermophilum gen. nov., sp. nov., a chemoorganotrophic, anaerobic, thermophilic bacterium. Int. J. Syst. Bacteriol. 35:253-259.

30. Schink, B. 1984. Fermentation of tartrate enantiomers by anaerobic bacteria and description of two new species of strict anaerobes, Ruminococcus pasteurii and Ilyobacter tartaricus. Arch. Microbiol. 139:409-414.

31. Smibert, R. M., and N. R. Krieg. 1981. General characterization, p. 409-443.
In P. Gerhardt, R. G. E. Murray, R. N. Costilow, E. W. Nester, W. A. Wood N. R. Krieg, and G. B. Phillips (ed.), Manual of methods for general bacteriology. American Society for Microbiology, Washington, D.C.

32. Tanaka, K., K. Nakamura, and E. Mikami. 1991. Fermentation of S-citramalate, citrate, mesaconate and pyruvate by a gram-negative strictly anaerobic non-spore-former, Formivibrio citricus gen. nov., sp. nov. Arch. Microbiol. 155:491-495.

33. Trüper, H. G., and H. G. Schlegel. 1964. Sulphur metabolism in Thiorhodaceae. I. Quantitative measurements on growing cells of Chromatium okenii. Antonie Leeuwenhoek 30:225-238.

34. Widdel, F., and F. Bak. 1992. Gram-negative mesophilic sulfate-reducing bacteria, p. 3352-3378. In A. Balows, H. G. Trüper, M. Dworkin, W. Harder, and $\mathrm{K}$. H. Schleifer (ed.), The prokaryotes. A handbook on the biology of bacteria: ecophysiology, isolation, identification, applications, 2nd ed. Springer-Verlag, New York, N.Y.

35. Wiegel, J. 1992. The obligately anaerobic thermophilic bacteria, p. 105-184. In J. K. Kristjansson (ed.), Thermophilic bacteria. CRC Press, Boca Raton, Fla.

36. Windberger, E., R. Huber, A. Trincone, H. Fricke, and K. O. Stetter. 1989. Thermotoga thermarum sp. nov. and Thermotoga neapolitana occurring in African continental solfataric springs. Arch. Microbiol. 151:506-512.

37. Wolin, E. A., M. J. Wolin, and R. S. Wolfe. 1963. Formation of methane by bacterial extracts. J. Biol. Chem. 238:2882-2886. 